\title{
EFFECT OF SOME THERAPY FUNCTIONAL FOODS ON BONE HEALTH IN OSTEOPOROTIC RATS
}

\author{
[119] \\ Abd Allah ${ }^{1 *}$ M.A., Kishk ${ }^{2}$ Y.F., Anaam K. Ahmed ${ }^{1}$ and Magda H. Allam ${ }^{2}$ \\ 1- Medicinal Food Dept., National Organization for Drug Control and Research (NODCAR), \\ Giza, Egypt. \\ 2- Food Sci. Dept., Fac. of Agric., Ain Shams Univ., P.O.B 68, Hadayek Shoubra 11241, Cairo, \\ Egypt.
}

*Corresponding author: Mohamed.awad32@gmail

Received 24 March, $2019 \quad$ Accepted 14 April, 2019

\begin{abstract}
This study was conducted to demonstrate the effect of feeding on defatted soy bean and flaxseed flour as protein and phytoestrogen sources; broccoli and red cabbage as antioxidant sources; in addition to skimmed milk powder as a calcium source in prevention of bone loss and cell damage that usually accompanies aging process. Raw materials were subjected to proximate analysis and biologically evaluation on ninety six 4 month aged female albino rats. Eight rats were regarded as an initial group. Other eight rats were hold as a normal negative control group and fed on a basal diet. The remaining rats were ovariectomized and fed on low calcium diet for 8 weeks to produce osteoporosis model. Osteoporotic rats were divided into 9 groups (each of 8 rats) fed on standard diet supplemented with: I) soy bean flour, II) soy bean flour and broccoli, III) soy bean flour and red cabbage, IV) soy bean flour and mixture of broccoli and red cabbage, V) defatted flaxseed, VI) defatted flaxseed and broccoli, VII) defatted flaxseed and red cabbage, VIII) defeated flaxseed and mixture of broccoli and red cabbage. Skimmed milk powder and vitamin $D$ were added to the diet of each tested group. One group was kept as a positive control and fed on a standard diet. The results showed a decreases in body weight, changes in relative weight of kidney and liver organs, physical properties of bone, also decreases in serum and bone minerals including; calcium, magnesium and phosphorus in osteoporotic model .A decreasing in estradiol and increasing in parathyroid hormone as a bone marker were also found. Results observed in tested groups showed that the highest recovery
\end{abstract}

for the parameters were found in group IV which fed on standard diet supplemented with soy bean flour and mixture of broccoli and red cabbage followed by group VIII which fed on standard diet supplemented with defatted flaxseed and a mixture of broccoli and red cabbage. Therefore, it could be concluded that the aforementioned mixtures may be a promising sources to produce a functional food for prevention of bone loss and cell damage.

Keywords: Bones; Osteoporosis; Soy bean; Flaxseed; Red cabbage; Broccoli

\section{INTRODUCTION}

Bone mass is the result of a lifelong balance between the processes of bone formation and bone resorption, and in fact, most metabolic bone diseases, including osteoporosis, are a consequence of an unbalanced bone turnover. Osteoporosis is a type of bone disease that leads to an increased risk of fracture in the lumbar vertebrae and the hips, as well as other problems. Osteoporosis is the most common skeletal disorder that affects both genders, but most importantly affects female who feels more rapid loss of their bone mass during the early years following menopause (Yoo and Park, 2018).

Soy might be major functional food components with the potential to maintain bone health, soy bean contains a complex mixture of biologically active chemical components ; one of the main constituents of the soy bean beneficial to health is the isoflavones, it is a rich source of phytoestrogens, which are non-steroidal estrogens of 
the isoflavone class (Huang et al 2006), soy isoflavones, genistein, daidzein and its metabolite equol, have structural similarities to estradiol, exhibiting weakly estrogenic action by binding to estrogen receptors (Wong et al 2009). The isoflavones exhibit greater affinities for the estrogen receptor- $\beta$ than for the estrogen receptor- $\alpha$.Thus, isoflavones prevent bone loss (Griel et al 2012).

Flaxseed plant contains substances which promote good health; it is a rich source of lignans, polyunsaturated fatty acids, soluble and insoluble dietary fibers, B vitamins group, magnesium, and manganese (Figueiredo et al 2017). Flaxseed is high in phytochemicals, including many antioxidants, it is perhaps our best source of lignans which may promote fertility, reduce premenopausal symptoms. Therefore, it may reduce the risk of osteoporosis, systemic inflammation, cardiovascular disease and improve the adverse effects of the lack of estrogen, which starts during perimenopause (Ganorkar and Jain, 2013).

Because the lignans, and estrogen therapy may modulate bone metabolism through similar mechanisms of action, the overall hypothesis is that flaxseed will protect against deterioration of bone tissue and will enhance the protective effect of lower doses of estrogen therapy by attenuating the rate of bone turnover while exerting no adverse effects on uterus (Figueiredo et al 2017).

Cruciferous vegetables such as broccoli and red cabbage are rich sources of dietary antioxidants, such as vitamin $C, \beta$-carotene, and other carotenoids, including the lutein, zeaxanthin, and lycopene and other antioxidant components (Samec et al 2017). These antioxidants in cruciferous vegetables have the highest singlet oxygenquenching properties which are thought to protect against oxidative stress and prevent osteoporosis. Sulforaphane and isothiocyanate compound of cruciferous vegetables protects from oxidative stress, inflammation and radiation injury (Tilg, 2015). Also cruciferous vegetables are rich in flavonoids which have been found to inhibit trabecular bone loss caused by estrogen deficiency in ovariectomized rats (Chiba et al 2003)

The antioxidant properties of broccoli and red cabbage, which reduce the production of oxidationderived free radicals from the bone resorbing osteoclasts, and their high affinity for binding to estrogen receptors account for their beneficial action in preventing bone loss and suggest a promising role of these compounds for the treatment of bone loss (Forte et al 2016).

A majority of people consider milk and its products to be dependable sources of calcium and complete proteins. Dried skimmed milk is made by removing fat and almost all moisture from milk followed by pulverization skimmed milk. It is good quality mineral source, especially calcium (Fardellone et al 2017). Skimmed milk consumption can stimulate an increase in bone mineral deposition; also skimmed milk supplementation lowers the levels of bone turnover markers (Kruger et al 2006). High calcium intakes did results in bone marker changes and the increased retention of calcium in their cohort was due to suppression of bone resorption also increased absorption of calcium. Importantly, biochemical markers of bone formation and resorption in young healthy females are predictive of bone turnover rates (Wastney et al 2000).

The aim of this work is to study the possibility of using sources of protein and phytoestrogen, such as soy bean flour and defatted flaxseed and sources of antioxidants such as broccoli and red cabbage in addition to skimmed milk powder as a best source of calcium and vitamin $D$ to evaluate the role of these functional food for bone health and prevention of bone loss and cell damage that accompanies aging process.

\section{MATERIALS AND METHODS}

\section{Raw material}

Defatted soy bean flour and flaxseed were obtained from Food Technology and Reaserch Institute, Agricultural Research Center, Giza. Egypt. Skimmed milk was purchased from Davisco Food International Company. Red cabbage; broccoli, starch and corn oil were obtained from local market.

\section{Experiment design}

Ninety six, 4 month aged female albino rats weighting 190-200g were used in this study. The rats were adapted for two weeks through fed on basal diet. Eight rats were randomly chosen as an initial group, the rats were weighed and blood samples were taken from retro bulbar venous plexus (Shermer, 1967). Serum was separated and estimated for its biochemical analysis, then rats were sacrificed and organs were excised and weighed, also femoral bones for each rat were dissected, weighed and subjected to chemical and physical properties of bone. Other eight rats were also randomly chosen as a negative control group and fed on the standard diet till the end of the experiment. 
The remaining 80 rats were ovariectomized and fed on low calcium diet $(0.01 \%)$ for 60 days to induce osteoporotic model. At the end of feeding period, 8 rats were randomly chosen and weighed, blood samples was separated and estimated for serum biochemical analysis, then rats were sacrificed and subjected to all the studied parameters at the onset of experiment.

The remaining 72 ovariectomized rats were randomly divided into 9 groups (each of eight) rats as follows:-

Control positive: rats group fed on standard diet; Group I: fed on soy bean flour; Group II: fed on soy bean flour and supplemented with $5 \%$ broccoli; Group III: fed on soy bean flour and supplemented with $5 \%$ red cabbage; Group IV: fed on soy bean flour and supplemented with $5 \%$ mixture of broccoli and bed cabbage; Group V: fed on defatted flaxseed; Group VI: fed on defatted flaxseed and supplemented with 5\% broccoli; Group VII: fed on defatted flaxseed and supplemented with $5 \%$ red cabbage; Group VIII: fed on defatted flaxseed and supplemented with $5 \%$ of mixture of broccoli and red cabbage

All the tested diet groups were supplemented with skimmed milk powder as a source of calcium (25\% of diet) and vitamin D (10000 IU/ $/ \mathrm{kg}$ of diet). The feeding period was 60 days, at the end of experiment, rats were weighed, blood samples were taken and serum were separated and estimated for their biochemical analysis, rats were then sacrificed and organs were excised and weighed, femoral bones were also separated, weighed and subject to chemical and physical analysis.

\section{Analytical methods}

\section{Proximate analysis}

Protein, fat, fiber, ash, moisture and vitamins were determined in raw materials according to AOAC, (2016). Minerals in bone were determined by atomic absorption spectrophotometer (Perkin Elmer100) as mentioned by Deyhim et al (2003).

\section{Serum biochemical analysis}

Serum total calcium and magnesium were determined by the method of Gindler and King, (1972). Phosphorus was determined according to the method of El-Merzabani et al (1977). Parathyroid hormone (PTH) was determined by the method of Bouillon et al (1990). Estradiol $\left(E_{2}\right)$ was determined according to the method of Ratcliffe et al (1988).

\section{Physical properties of bones}

Weight and length of femur were measured; hardness, thickness and diameter were carried out using Hardness Tester Schileuniger model 6.D. Bone density was calculated by Archimedes principle according to Muhammad et al (2013).

\section{Statistical analyses}

The results were statistically analyzed according to SAS, (1999). Duncan's at $5 \%$ level of significance was used to compare between means according to Snedecor and Cochran, (1980).

\section{RESULTS AND DISCUSSIONS}

Data in Table (1) show that, soy flour characterized by the highest protein content followed by flaxseed, skimmed milk and broccoli being 56.0, $37.0,35.2$ and $28.0 \%$ respectively, while red cabbage showed the lowest protein content $9.4 \%$. The highest fat content was found in broccoli $5.8 \%$ followed by soy bean $4.2 \%$, while the lowest content was found in flaxseed $2.3 \%$.

The highest content of fiber was found in red cabbage (30.4\%) then broccoli (19\%), while a negligible quantity $2 \%$ was found in skimmed milk. On the other hand, the highest ash content was found in skimmed milk (9.2\%) and the lowest quantity $(5.9 \%)$ was found in flaxseed and red cabbage. Moreover, red cabbage and skimmed milk contain a high amount of carbohydrate $(51.5 \%$ and $50.6 \%$, respectively), followed by broccoli and flaxseed (38.7\% and $37.6 \%$, respectively), while the lowest quantity $(19 \%)$ was found in soy flour. These results are on line with those obtained by Kahlon et al (2008) and Soltan, (2013).

As shown in Table (2), skimmed milk contains the highest calcium concentration (1300mg) while, red cabbage and broccoli contain the lowest content being 40 and $37 \mathrm{mg}$, respectively. Magnesium concentration in flaxseed was $310 \mathrm{mg}$ followed by soy flour $(275 \mathrm{mg})$, while a negligible concentrations (16 and $18 \mathrm{mg}$, respectively) were found in red cabbage and broccoli. Soy flour showed the highest phosphorus concentration (540mg), followed by flaxseed, skimmed milk then broccoli (341,114 and 54mg, respectively), while the lowest concentration was found in red cabbage (33mg). These results are in agreedment with those obtained by Soltan, (2013).

The data in Table (2) showed that, broccoli and red cabbage are rich in vitamins. Broccoli had the 
highest content in vitamins; $\mathrm{C}, \mathrm{E}$ and $\mathrm{K}$ being $133 \mathrm{mg}, 1.5 \mathrm{mg}$ and $71 \mu \mathrm{g}$ respectively, followed by red cabbage being $97 \mathrm{mg}, 0.2 \mathrm{mg}$ and $38 \mu \mathrm{g}$, respectively. Vitamin D was found only in skimmed milk $(3.6 \mu \mathrm{g})$. These results are in agreedment with those obtained by Kahlon et al (2008) and Dias, (2012).

Table 1. Proximate analyses of raw materials (\% dry basis)

\begin{tabular}{|c|c|c|c|c|c|c|}
\hline Components & Moisture & \multicolumn{5}{|c|}{$\%$ Dry basis } \\
\hline Materials & & Protein & Fat & Fibers & Ash & ${ }^{*}$ Carbohydrate \\
\hline Soy bean flour & $3.9^{\mathrm{b}}$ & $56.0^{\mathrm{a}}$ & $4.2^{\mathrm{b}}$ & $13.0^{\mathrm{c}}$ & $7.8^{\mathrm{b}}$ & $19.0^{\mathrm{c}}$ \\
Defatted flaxseed & $5.7^{\mathrm{a}}$ & $37.0^{\mathrm{b}}$ & $2.3^{\mathrm{d}}$ & $17.2^{\mathrm{b}}$ & $5.9^{\mathrm{c}}$ & $37.6^{\mathrm{b}}$ \\
Skimmed milk & $3.8^{\mathrm{b}}$ & $35.2^{\mathrm{b}}$ & $3.0^{\mathrm{c}}$ & $2.0^{\mathrm{d}}$ & $9.2^{\mathrm{a}}$ & $50.6^{\mathrm{a}}$ \\
Broccoli & $4.0^{\mathrm{b}}$ & $28.0^{\mathrm{c}}$ & $5.8^{\mathrm{a}}$ & $19.0^{\mathrm{b}}$ & $8.5^{\mathrm{ab}}$ & $38.7^{\mathrm{b}}$ \\
Red cabbage & $5.4^{\mathrm{a}}$ & $9.4^{\mathrm{d}}$ & $2.8^{\mathrm{c}}$ & $30.4^{\mathrm{a}}$ & $5.9^{\mathrm{c}}$ & $51.5^{\mathrm{a}}$ \\
\hline
\end{tabular}

$(\mathrm{n}=3)$, *calculated by difference

Means in the same column with different superscript litters are significantly different $(p<0.05)$.

Table 2. Mineral and vitamins in raw materials $/ 100 \mathrm{~g}$

\begin{tabular}{|c|c|c|c|c|c|c|c|}
\hline Components & \multicolumn{3}{|c|}{ Minerals } & \multicolumn{4}{c|}{ Vitamins } \\
\hline Materials & $\begin{array}{c}\text { Ca } \\
(\mathbf{m g})\end{array}$ & $\begin{array}{c}\mathbf{M g} \\
(\mathbf{m g})\end{array}$ & $\begin{array}{c}\mathbf{P} \\
(\mathbf{m g})\end{array}$ & $\begin{array}{c}\mathbf{D} \\
(\boldsymbol{\mu g})\end{array}$ & $\begin{array}{c}\mathbf{K} \\
(\boldsymbol{\mu g})\end{array}$ & $\begin{array}{c}\mathbf{E} \\
(\mathbf{m g})\end{array}$ & $\begin{array}{c}\mathbf{C} \\
(\mathbf{m g})\end{array}$ \\
\hline Soy flour & $280^{\mathrm{b}}$ & $275^{\mathrm{b}}$ & $540^{\mathrm{a}}$ & - & $3.1^{\mathrm{c}}$ & $0.7^{\mathrm{b}}$ & $90^{\mathrm{b}}$ \\
Flaxseed & $190^{\mathrm{c}}$ & $310^{\mathrm{a}}$ & $341^{\mathrm{b}}$ & - & $2.5^{\mathrm{c}}$ & $0.8^{\mathrm{b}}$ & $70^{\mathrm{c}}$ \\
Skimmed milk & $1300^{\mathrm{a}}$ & $110^{\mathrm{c}}$ & $114^{\mathrm{c}}$ & $3.6^{\mathrm{a}}$ & - & - & $21^{\mathrm{d}}$ \\
Broccoli & $37^{\mathrm{d}}$ & $16^{\mathrm{d}}$ & $54^{\mathrm{d}}$ & - & $71^{\mathrm{a}}$ & $1.5^{\mathrm{a}}$ & $133^{\mathrm{a}}$ \\
Red cabbage & $40^{\mathrm{d}}$ & $18^{\mathrm{d}}$ & $33^{\mathrm{e}}$ & - & $38^{\mathrm{b}}$ & $0.2^{\mathrm{c}}$ & $97^{\mathrm{b}}$ \\
\hline
\end{tabular}

Means in the same column with different superscript litters are significantly different $(p<0.05)$.

The changes in biochemical parameters in serum and bone of osteoporotic rats (Table 3 ) showed a significant decrease in body weight, while the relative weight of the internal organs; liver and kidney exhibited significant increases. These increases due to osteoporotic which caused an enlargement in size and weight of liver and kidney cells through the increase infiltration of lipids.

A significant decrease in serum and femoral bone minerals ( $\mathrm{Ca}, \mathrm{Mg}$ and $\mathrm{P}$ ) were obtained, also significant decreases in $\mathrm{E}_{2}$ and increase in $\mathrm{PTH}$ as bone markers were found. The decrease in serum and bone Ca may be attributed to the hyperthyroidism results from deficiency of $\mathrm{Ca}$ caused from feeding with low $\mathrm{Ca}$ diet for 8 weeks. These decreases were caused also by reducing $\mathrm{Ca}$ absorption and promote renal $\mathrm{Ca}$ excretion that inhibit osteoblastic bone formation and impair intestinal Ca excretion which affected by osteoporosis. These observations are in accordance with those of Goodman et al (2007) and Soltan, (2013).

Changes in physical properties of femoral bone were also observed at the end of feeding period on low $\mathrm{Ca}$ diet including significant decreases in weight, length, diameters, hardness, thickness and density in osteoporotic rats as seen in Table (3). These decreases were attributed to the loss of bone mass following ovariectomy which negatively affected the physicals and strength femur bone. Similar results were observed by Hinton et al (2018). 
Table 3. Changes in some biochemical properties and physical properties in serum and femoral bone of female albino rats fed on law calcium diet for 8 weeks.

\begin{tabular}{|c|c|c|c|}
\hline Parameters & Initial group & Osteoporotic group & $\%$ changes \\
\hline \multicolumn{4}{|c|}{$\begin{array}{l}\text { Body weight } \\
\text { Organs weight \% }\end{array}$} \\
\hline Liver & 4.20 & 6.40 & 52.3 \\
\hline Kidney & 1.10 & 1.87 & 70 \\
\hline Heart & 0.59 & 0.59 & - \\
\hline \multicolumn{4}{|l|}{ Serum } \\
\hline $\mathrm{Ca}(\mathrm{mg} / \mathrm{dL})$ & 12.40 & 10.81 & $12.8-$ \\
\hline $\mathrm{Mg}(\mathrm{mg} / \mathrm{dL})$ & 3.84 & 3.05 & 20.6- \\
\hline$P(m g / d L)$ & 8.20 & 6.55 & $20.2-$ \\
\hline $\mathrm{E}_{2} \mathrm{pg} / \mathrm{ml}$ & 31.60 & 17.28 & -45.3 \\
\hline PTH pg/ml & 37.80 & 64.79 & 71.4 \\
\hline \multicolumn{4}{|l|}{ Femur bone } \\
\hline Weight (mg) & 376 & 311 & -17.3 \\
\hline Length(cm) & 2.84 & 2.40 & -15.5 \\
\hline Diameter(N) & 41.1 & 32.5 & -21 \\
\hline Hardness (kp) & 5.8 & 2.8 & -51.7 \\
\hline Thickness (mm) & 9.1 & 6.7 & -26.4 \\
\hline Density $\left(\mathrm{g} / \mathrm{cm}^{3}\right)$ & 1.33 & 0.98 & -26.3 \\
\hline $\mathrm{Ca}$ & 134.3 & 80.5 & -40 \\
\hline $\mathrm{Mg}$ & 34.1 & 20.1 & -41 \\
\hline$P$ & 78.4 & 48.5 & -38.1 \\
\hline
\end{tabular}

$(n=8)$ Mean in the same column with different superscript litters are significantly different $(p<0.05)$.

It was clearly noticed from Table (4). That osteoporotic rats which showed a loss in their body weight caused by ovariectomy, when fed on diets containing the different sources of protein, phytoestrogen and antioxidant sources for 60 days led to significant increases in their body weight compared to positive control rats group which fed on the standard diet. Non-significant changes in body weight were found among all the tasted animals groups; they practically gained an equal weight ranging between 55.0 gains $62.3 \mathrm{~g}$ compared to $40.2 \mathrm{~g}$ in the positive control group

The results in the same Table showed also average values of relative internal organs weight to body weight of the eight groups fed on different supplemented diet. Generally, feeding on the tested diets for 60 days caused significant decreases in these organs weight compared to those of the positive control rats group, reaching values closed to those of the normal control rats; after increasing organs weight by reason of ovariectomy. The best results decreases in kidney weight were observed in groups (II) fed on soy flour with a mixture of broccoli cabbage, groups (VI) and (VIII) fed on flaxseed diet mixture with broccoli and red cabbage, respectively However, the best groups which observed significant decreases in liver weight were (VIII) followed by (IV) which fed on flaxseed and soy flour diets each were mixed with broccoli and red cabbage. Non-significant changes in heart weight among all tested and control groups were found. These results are agreed with those of Soltan, (2013) and Alkhamees et al (2017). 
Table 4. Finals body weight $(\mathrm{BW} / \mathrm{g})$ and relative internal organs weight $(\mathrm{g} / 100 \mathrm{~g})$ of osteoporotic female albino rats fed on different diets for 60 days

\begin{tabular}{|c|c|c|c|c|c|c|}
\hline \multirow{2}{*}{$\begin{array}{c}\text { Animal } \\
\text { group }\end{array}$} & \multicolumn{2}{|c|}{ (BW/g) } & \multirow{2}{*}{ (BWG/g) } & \multicolumn{3}{|c|}{ Relative organs weight (g/100g) } \\
\cline { 2 - 3 } \cline { 5 - 6 } & Osteoporotic & Final & & Heart & Kidney & Liver \\
\hline Control(-) & $248.4^{\mathrm{a}}$ & $296.2^{\mathrm{a}}$ & $47.8^{\mathrm{b}}$ & $0.60^{\mathrm{a}}$ & $1.30^{\mathrm{d}}$ & $4.64^{\mathrm{e}}$ \\
Control(+) & $152.6^{\mathrm{b}}$ & $192.8^{\mathrm{c}}$ & $40.2^{\mathrm{b}}$ & $0.62^{\mathrm{a}}$ & $1.73^{\mathrm{a}}$ & $6.03^{\mathrm{a}}$ \\
1 & $153.1^{\mathrm{b}}$ & $214.9^{\mathrm{b}}$ & $61.8^{\mathrm{a}}$ & $0.61^{\mathrm{a}}$ & $1.54^{\mathrm{b}}$ & $5.58^{\mathrm{b}}$ \\
II & $152.2^{\mathrm{b}}$ & $214.5^{\mathrm{b}}$ & $62.3^{\mathrm{a}}$ & $0.62^{\mathrm{a}}$ & $1.40^{\mathrm{c}}$ & $5.24^{\mathrm{c}}$ \\
III & $153.5^{\mathrm{b}}$ & $213.7^{\mathrm{b}}$ & $60.2^{\mathrm{a}}$ & $0.61^{\mathrm{a}}$ & $1.53^{\mathrm{b}}$ & $5.09^{\mathrm{cd}}$ \\
IV & $155.3^{\mathrm{b}}$ & $216.7^{\mathrm{b}}$ & $61.4^{\mathrm{a}}$ & $0.60^{\mathrm{a}}$ & $1.51^{\mathrm{b}}$ & $4.90^{\mathrm{d}}$ \\
V & $155.1^{\mathrm{b}}$ & $210.1^{\mathrm{b}}$ & $55.0^{\mathrm{bc}}$ & $0.62^{\mathrm{a}}$ & $1.53^{\mathrm{b}}$ & $5.24^{\mathrm{c}}$ \\
VI & $154.9^{\mathrm{b}}$ & $211.5^{\mathrm{b}}$ & $56.6^{\mathrm{bc}}$ & $0.59^{\mathrm{a}}$ & $1.40^{\mathrm{c}}$ & $5.03^{\mathrm{cd}}$ \\
VII & $152.8^{\mathrm{b}}$ & $212.5^{\mathrm{b}}$ & $59.7^{\mathrm{a}}$ & $0.62^{\mathrm{a}}$ & $1.54^{\mathrm{b}}$ & $5.05^{\mathrm{cd}}$ \\
VIII & $155.5^{\mathrm{b}}$ & $215.4^{\mathrm{b}}$ & $59.9^{\mathrm{a}}$ & $0.60^{\mathrm{a}}$ & $1.41^{\mathrm{c}}$ & $4.87^{\mathrm{d}}$ \\
\hline
\end{tabular}

$(n=8)$. Mean \pm SD. Mean in the same column with different superscript litters are significantly different $(p<0.05)$

Negative control: rats fed on standard diet

Positive control: osteoporotic rats fed on standard diet Group I: osteoporotic rats fed on soy flour

Group II: osteoporotic rats fed on soy flour and 5\% Broccoli
Group IV: osteoporotic rats fed on soy flour and (5\% Broccoli + red cabbage)

Group V: osteoporotic rats fed on flaxseed

Group VI: osteoporotic rats fed on flaxseed and 5\% Broccoli

Group VII: osteoporotic rats fed on flaxseed and $5 \%$ red cabbage

Group III: osteoporotic rats fed on soy flour and 5\% red Group VIII: osteoporotic rats fed on flaxseed and (5\% Broccoli + cabbage red cabbage)

After decreasing of serum $\mathrm{Ca}, \mathrm{Mg}$ and $\mathrm{P}$ in ovariectomized rats fed on low $\mathrm{Ca}$ diet, significant increases in these minerals in all the treated groups were found after feeding on the supplemented diets for 60 days (Table 5). The best recovery of $\mathrm{Ca}$ and $\mathrm{P}$ were found in groups (IV) and (VIII). Concerning Mg, all the treated groups statistically showed the same values being more than its concentration in serum of the positive control group and lesser than in serum of normal rats group. These results were agreed with those of Napoli et al (2007)

As shown in Table (5). All the treated group of osteoporotic rats which fed on supplemented diets for 60 days, showed significant increases in $E_{2}$ and decreases in PTH levels in their serum compared to those of positive control rats; while the obtained values did not recover the levels of these hormones in serum of normal rats in the negative control group. The higher increases in $E_{2}$ were observed in group (II), group (IV) and group (VIII). While, among PTH hormone, all the treated groups significantly showed the same values.

The increasing of serum $E_{2}$ in rats groups fed on soy flour diets was due to soy-derived isoflavones such as genistein and diadzein which their structure are similar to $E_{2}$; they have positive effects on bone health and exert the greatest biolog- ical impact on bone metabolism when endogenous levels of sex hormones are low. Also, increasing levels of bone markers were observed in rats fed on flaxseed diets by both serum $\mathrm{E}_{2}$ and PTH activity. However, the decreasing in PTH was due to phytoestrogen supplemented by soy flour and flaxseed. These decrease in bone loss mass led to osteoporosis.

Broccoli and red cabbage were also connected to hormonal balance by their effect on how the body breaks down estrogen. The antioxidant properties in these cruciferous vegetables which reduce the production of oxidation-derived free radical from the bone resorbing osteoclasts, and their high affinity for binding to estrogen receptors, account for their beneficial action in preventing bone loss and suggest a promising role of these compounds for the treatment of osteoporosis. Theses observation are in agreed with those of Sharan et al (2009); Ward et al (2010) and Micheal et al (2011).

Data in Table (6) showed a significant increasing in $\mathrm{Ca}, \mathrm{Mg}$ and $\mathrm{P}$ in femoral bone of osteoporotic treated groups fed on the tested diets for 60 days compared to the positive control rats groups. Bone rats groups IV and VIII showed the highest Ca content, statistically covered its concentration in the normal femoral bone of the negative control 
group. However, $\mathrm{P}$ content in femoral bone in all the treated rats, except I, V and VII groups, significantly covered its content in bone of negative control rats. On the other side, $\mathrm{Mg}$ concentration in bone of all treated groups was statistically the same and not covered its value in bone of normal rats; one exception, rats in $\mathrm{V}$ group fed on diet contained flaxseed flour only showed significantly lower value being statistically equal to that of the positive control group.
The obtained results revealed that gensitein in soybean flour had high significant effect on minerals content of rats femoral bone. Also, flaxseed flour may reduce organic acids and metabolic associated with bone demineralization contributing to bone tissue stiffness and resistance. In addition higher vegetable had a positive effect on bone mineral. These finding are in line with those of Prynne et al (2006) and Abreu Maira et al (2018).

Table 5. Serum Minerals $(\mathrm{mg} / \mathrm{dL})$ and hormones markers $(\mathrm{pg} / \mathrm{ml})$ of Osteoporotic female albino rats fed different diets for 60 days

\begin{tabular}{|c|c|c|c|c|c|}
\hline \multirow{2}{*}{ Animal groups } & \multicolumn{3}{|c|}{ Minerals } & \multicolumn{2}{c|}{ Hormones } \\
\cline { 2 - 6 } & Ca & Mg & P & E2 & PTH \\
\hline Control (-) & $12.83^{\mathrm{a}}$ & $4.16^{\mathrm{a}}$ & $8.61^{\mathrm{a}}$ & $29.30^{\mathrm{a}}$ & $39.05^{\mathrm{c}}$ \\
Control (+) & $10.98^{\mathrm{d}}$ & $3.13^{\mathrm{c}}$ & $6.66^{\mathrm{d}}$ & $16.70^{\mathrm{e}}$ & $61.04^{\mathrm{a}}$ \\
I & $12.27^{\mathrm{c}}$ & $3.54^{\mathrm{b}}$ & $8.31^{\mathrm{bc}}$ & $20.23^{\mathrm{d}}$ & $47.23^{\mathrm{b}}$ \\
II & $12.36^{\mathrm{bc}}$ & $3.55^{\mathrm{b}}$ & $8.33^{\mathrm{bc}}$ & $24.11^{\mathrm{b}}$ & $48.11^{\mathrm{b}}$ \\
III & $12.33^{\mathrm{bc}}$ & $3.55^{\mathrm{b}}$ & $8.34^{\mathrm{bc}}$ & $22.31^{\mathrm{c}}$ & $47.21^{\mathrm{b}}$ \\
IV & $12.55^{\mathrm{b}}$ & $3.58^{\mathrm{b}}$ & $8.60^{\mathrm{a}}$ & $23.89^{\mathrm{b}}$ & $47.05^{\mathrm{b}}$ \\
V & $11.26^{\mathrm{c}}$ & $3.56^{\mathrm{b}}$ & $7.96^{\mathrm{c}}$ & $20.13^{\mathrm{d}}$ & $47.42^{\mathrm{b}}$ \\
VI & $12.25^{\mathrm{c}}$ & $3.57^{\mathrm{b}}$ & $8.08^{\mathrm{c}}$ & $20.23^{\mathrm{d}}$ & $47.23^{\mathrm{b}}$ \\
VII & $12.26^{\mathrm{c}}$ & $3.54^{\mathrm{b}}$ & $7.97^{\mathrm{c}}$ & $22.41^{\mathrm{c}}$ & $48.20^{\mathrm{b}}$ \\
VIII & $12.52^{\mathrm{b}}$ & $3.56^{\mathrm{b}}$ & $8.40^{\mathrm{b}}$ & $24.30^{\mathrm{b}}$ & $46.20^{\mathrm{b}}$ \\
\hline
\end{tabular}

$(n=8)$. Mean in the same column with different superscript litters are significantly different $(p<0.05)$.

Groups abbreviations see in Table (4)

Table 6. Physical properties and minerals in femoral bone of osteoporotic female albino rats fed on different diets for 60 days

\begin{tabular}{|c|c|c|c|c|c|c|c|c|c|}
\hline \multirow{2}{*}{$\begin{array}{l}\text { Animal } \\
\text { group }\end{array}$} & \multicolumn{6}{|c|}{ Physical properties } & \multicolumn{3}{|c|}{ Minerals $\mathrm{mg} / \mathrm{g}$} \\
\hline & $\begin{array}{l}\text { Weight } \\
\text { (mg) }\end{array}$ & $\begin{array}{l}\text { Length } \\
\text { (cm) }\end{array}$ & $\begin{array}{c}\text { Diameter } \\
(\mathrm{N})\end{array}$ & \begin{tabular}{|c|}
$\begin{array}{c}\text { Hardness } \\
(\mathrm{kp})\end{array}$ \\
\end{tabular} & $\begin{array}{c}\text { Thickness } \\
(\mathrm{mm})\end{array}$ & $\begin{array}{l}\text { Density } \\
\left(\mathrm{g} / \mathrm{cm}^{3}\right)\end{array}$ & $\mathrm{Ca}$ & Mg & $\mathbf{P}$ \\
\hline Control (-) & $378^{a}$ & $2.88^{a}$ & $43.8^{a}$ & $6.2^{a}$ & $9.4^{a}$ & $1.41^{a}$ & $147.6^{a}$ & $39.9^{a}$ & $88.9^{a}$ \\
\hline Control (+) & $322^{d}$ & $2.40^{\mathrm{C}}$ & $34.5^{b}$ & $3.7^{c}$ & $7.5^{c}$ & $1.07^{d}$ & $95.0^{d}$ & $24.8^{c}$ & $57.5^{c}$ \\
\hline 1 & $351^{b}$ & $2.83^{a}$ & $41.8^{\mathrm{a}}$ & $5.1^{b}$ & $8.2^{b}$ & $1.21^{\mathrm{c}}$ & $133.9^{b}$ & $32.8^{b}$ & $81.4^{b}$ \\
\hline II & $351^{b}$ & 2. $50^{\mathrm{b}}$ & $44.2^{a}$ & $5.9^{a}$ & $9.1^{\mathrm{a}}$ & $1.32^{b}$ & $134.8^{b}$ & $33.5^{b}$ & $88.6^{a}$ \\
\hline III & $349^{b}$ & $2.55^{b}$ & $43.3^{a}$ & $5.9^{a}$ & $9.2^{a}$ & $1.23^{c}$ & $141.0^{\mathrm{ab}}$ & $33.5^{b}$ & $88.0^{a}$ \\
\hline IV & $369^{a b}$ & $2.86^{a}$ & $41.5^{a}$ & $6.0^{a}$ & $9.4^{a}$ & $1.35^{b}$ & $146.4^{a}$ & $34.2^{b}$ & $90.5^{a}$ \\
\hline V & $335^{c}$ & $2.84^{\mathrm{a}}$ & $42.9^{a}$ & $5.2^{b}$ & $8.4^{b}$ & $1.27^{\mathrm{bc}}$ & $125.1^{\mathrm{c}}$ & $26.1^{\mathrm{C}}$ & $79.4^{b}$ \\
\hline VI & $352^{b}$ & $2.84^{a}$ & $42.5^{a}$ & $5.1^{b}$ & $8.5^{b}$ & $1.26^{\mathrm{bc}}$ & $135.1^{\mathrm{b}}$ & $34.3^{b}$ & $89.5^{a}$ \\
\hline VII & $350^{\mathrm{b}}$ & $2.85^{\mathrm{a}}$ & $43.3^{a}$ & $5.2^{b}$ & $9.2^{\mathrm{a}}$ & $1.22^{c}$ & $133.9^{b}$ & $33.1^{b}$ & $80.3^{b}$ \\
\hline VIII & $370^{\mathrm{ab}}$ & $2.86^{a}$ & $44.3^{a}$ & $6.0^{\mathrm{a}}$ & $9.3^{a}$ & $1.34^{b}$ & $146.5^{a}$ & $34.3^{b}$ & $89.3^{a}$ \\
\hline
\end{tabular}

$(n=8)$ Mean in the same column with different superscript litters are significantly different $(p<0.05)$.

Groups abbreviations see in Table (4) 
Physical properties of femoral bone of osteoporotic rats are seen in Table (6). Results revealed that all tested groups showed significantly higher values in all the physical properties compared to positive control group values. The best recovery of all properties was observed in groups IV and VIII, especially weight and hardness which their values were significantly equal to those of the normal control groups. Also, rats fed on these two diets showed an improvement in femur thickness and density which beneficially affected by soy isoflavones diet and flaxseed flour rich in lignins which are structurally similar to tamoxifen that exert a positive effect on bone density, and may help to prevent osteoporosis induced by deficient estrogen. In addition supplementation with skimmed milk and cruciferous vegetables enhanced bone mass density and showed positive effects on its properties.

However, the length and diameter of femoral bone of all treated rats groups showed higher values compared to positive ovariectomized group and significantly equal to those of the normal control group. These increasing in bone cortical area support the increase in rats bone weight. These observations are agreed with those of Deyhim et al (2003); Sacco et al (2008) and Muguruma et al (2012).

From this study it could be concluded that the mixture of defatted soy bean or flaxseed flour as protein and phytoestrogen sources with broccoli and red cabbage rich in antioxidant sources; in addition to vitamin $\mathrm{D}$ and skimmed milk powder as Ca sources can be used as promising sources to produce a functional food to prevent bone loss an cell damage that accompanies aging process.

\section{REFERENCES}

Abreu Maira C.D., Leticia P.R., da-Costa R.L., Boueri F.B., Carolina P.R., Pereira D.A., Ribeiro C.D., da Silva M.E. and Gilson B.T. 2018. Flaxseed (Linum usitatissimum) flour contributes to bone health in adult male rats. Nutrition 49, 48-50.

Alkhamees A.O., Al-Roujayee A.S., Abuohashish H.M. and Ahmed M.M. 2017. Antiosteoporotic effects of an antidepressant tianeptine on ovariectomized rats. Biomedicine and Pharmacotherapy 87, 575-582.

AOAC, 2016. Official Methods of Analysis of Association of Official Analytical Chemists International $20^{\text {th }}$ (ed.), Pub. Washington, D.C., U.S.A.
Bouillon R., Coopmans W., De Groote E.H., Radoux D. and Eliard P.H. 1990. Immunoradiometric assay of parathyrin with polyclonal and monocolonal region specific antibodies. Clin. Chem., 36(2), 271-276.

Chiba H., Uehara M. and Wu J. 2003. Hesperidin, a citrus flavonoid, inhibits bone loss and decreases serum and hepatic lipids in ovariectomized mice. Nutrition J. 133, 1892-1897.

Deyhim F., Stoecker J.B., Brusewitz G.H. and Arjmandi B.H. 2003. The effects of estrogen depletion and isoflavones on bone metabolism in rats. Nutrition Research. 23,123-130.

Dias J.S. 2012. Nutritional Quality and Health Benefits of Vegetables: A Review. Food and Nutrition Sci., 3, 1354-1374.

El-Merzabani M.M., El-Aaser A.A. and Zakhary N.I. 1977. Phosphorus colorimetric method. J. Clin. Chem. Clin. Biochem. 15, 715-718.

Fardellone P., Séjourne A., Blain H., Cortet B., Thomas T. and Committee G.S. 2017. Osteoporosis: Is milk a kindness or a curse. Joint Bone Spine. 84, 275-281.

Figueiredo S.M., Maia L.A., Guarda D.S., Lisboa R.C. and de Moura E.G. 2017. Flaxseed secoisolariciresinol diglucoside (SDG) during lactation improves bone metabolism in offspring at adulthood. J. of Functional Foods 29, 161171.

Forte L., Torricelli P., Boanini E., Gazzano M., Rubini K., Fini M. and Bigi A. 2016. Antioxidant and bone repair properties of quercetinfunctionalized hydroxyapatite: An in vitro osteoblast-osteoclast-endothelial cell co-culture study. Acta Biomaterialia 32, 298-308.

Ganorkar P.M. and Jain R.K. 2013. Flaxseed - a nutritional punch. International Food Research J. 20, 19-25.

Gindler M. and King J.D. 1972. Determination of total calcium and magnesium in serum. Am. J. Clin. Path, 376 p.

Goodman S.B., Jiranck W., Petrow E. and Yasko A.W. 2007. The effects of medication on bone. J. of American Academy Orthopedic Surgeons. 15, 450-460.

Griel A.E., Kris-Etherton P.M., Hilpert K.F., Zhao G., West S.G., Gui C.G., Brašić J.R., Liu X.D., Gong G.Y., Zhang G.M., Liu C.J. and Gao G.Q. 2012. Bone mineral density in postmenopausal Chinese women treated with calcium fortification in soymilk and cow's milk. Osteoporosis. Int. 23, 1563-1570.

Hinton S.P., Ortinau C.L., Dirkes K.R., Shaw L.E., Richard W.M., Zidon Z.T., Britton L.S. and Koch G.L. 2018. Soy protein improves tibial whole-bone and tissue-level biomechanical 
properties in ovariectomized and ovary-intact, low-fit female rats. Bone Reports. 8, 244254.

Huang H.Y., Yang H.P., Yang H.T., Yang T.C., Shieh M.J. and Huang S.Y. 2006. One-year soy isoflavone supplementation prevents early postmenopausal bone loss but without a dosedependent effect. J. Nutr. Biochem.17, 509517.

Kahlon T.S., Chiu M.M. and Chapman M.H. 2008. Steam cooking significantly improves in vitro bile acid binding of collard greens, kale, mustard greens, broccoli, green bell pepper, and cabbage. Nutrition Research. 28, 351357.

Kruger C.M., Booth L.C., Coad J., Schollum M.L., Kuhn-Sherlock B. and Shearer J.M. 2006. Effect of calcium fortified milk supplementation with or without vitamin $\mathrm{K}$ on biochemical markers of bone turnover in premenopausal women. Nutrition 22, 1120-1128.

Micheal P., Bettina B.W., Helmut M., Detlaf N. and Corinna H. 2011. Effect of short-term vitamin $D_{3}$ and calcium supplementation on blood pressure and parathyroid hormone levels in Elderly women. J. Clinical Endocrinology \& Metabolism. 86(4), 1633-1637.

Muguruma M., Ahmed A.M., Kawahara S., Kusumegi K., Hishinuma Ohya T.K. and Nakamura T. 2012. A mixture of soybean and skimmed milk reduces osteoporosis in rats. J. of Functional Food 4(4), 810-818.

Muhammad S.I., Maznah I., Mahmud R.B., Esmaile, M.F. and Zuki A.Z. 2013. Bone mass density estimation: Archimede's principle versus automatic X-ray histogram and edge detection technique in ovariectomized rats treated with germinated brown rice bioactives. Clinical Interventions in Aging. 8, 1421-1431.

Napoli N., Thomposon J. and Civitell R.M. 2007. Effects of dietary calcium compared with calcium supplements on estrogen metabolism and bone mineral density. American J. of Clinical Nutrition. 85, 1428-1433.

Prynne C.J., Mishra G.D., Connell M.A., Muniz G., Laskey M.A., Yan L., Prentice A. and Ginty F. 2006. Fruit and vegetable intakes and bone mineral status: a cross sectional study in 5 age and sex cohorts. American J. of Clinical Nutrition 83, 1420-1428.

Ratcliffe W.A., Carter G.D. and Dowsett M. 1988. Estradiol assays: applications and guidelines for the provision of a clinical biochemistry service, Ann. Clin. Biochem. 25, 466-483.
Sacco S.M., Chen J.M., Power K.A., Ward W.E and Thompson L.U. 2008. Lignan-rich sesame seed negates the tumor-inhibitory effect of tamoxifen but maintains bone health in a postmenopausal athymic mouse model with estrogen-responsive breast tumors. Menopause. 15(1), 171-179.

Samec D., Pavlović I. and Salopek-Sondi B. 2017. White cabbage (Brassica oleracea var. capitata f. alba): botanical, phytochemical and pharmacological overview. Phytochem. 16, 117-136.

SAS, 1999. Statistical Analysis System, SAS Users Guide: Statistics. SAS Institute Inc. Editor, Cary. NC.

Sendecor G.W. and Cocharn W. 1980. Statistical Methods $7^{\text {th }}(e d)$. Aiwa Sate Univ., Press. Ames Aiwa,USA. 507 p.

Sharan K., Siddiqui J.A., Swarnkar G., Maurya R. and Chattopadhyay N. 2009. Role of phytochemicals in the prevention of menopausal bone loss: evidence from in vitro and in vivo, human interventional and pharmacokinetic studies. Cur. Med. Chem. 16, 1138-1157.

Shermer S. 1967. The blood morphology of the laboratory animals. $3^{\text {rd }}$ ed., F.A. Davis Co., Philadelphia, U.S.A. 42 p.

Soltan S.S.A. 2013. The Effects of Skimmed Milk, Soybean Flour and Sardine Fish Powder on Osteoporotic Female Rats. Middle-East J. of Scientific Research 15(7), 984-997.

Tilg H. 2015. Cruciferous vegetables: prototypic anti-inflammatory food components. Clinical Phytoscience, 2, 1-10.

Ward E.W., Lau B., Kaludjerovic J. and Sacco M.S. 2010. Functional foods and bone health: Where are we at?. Functional Food Product Development Edited by Jim Smith and Edward Charter. pp. 459-503

Wastney M.E., Martin B.R., Peacock M., Smith D. and Jackman X.Y. 2000. Changes in calcium kinetics in adolescent girls induced by high calcium intake. J. Clin Endocrinol Metab. 85, 44-70.

Wong W.W., Lewis R.D., Steinberg F.M., Murray M.J., Cramer M.A., Amato P., Young R.L., Barnes S., Ellis K.J. and Shypailo R.J. 2009. Soy isoflavone supplementation and bone mineral density in menopausal women: A 2-y multicenter clinical trial. Am. J. Clin. Nutr. 90, 1433-1439.

Yoo J.E. and Park Y.S. 2018. Prevalence and associated risk factors for osteoporosis in Korean men. Archives of Osteoporosis.13, 8288. 



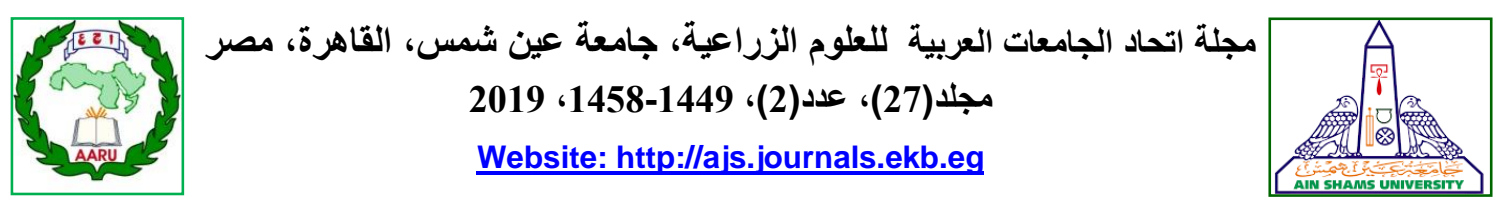 \\ 1458}

تأثير بعض الأغذية الوظيفية العلاجية على صحة العظام في الفئران المصابة بهثاثة العظام

$$
\begin{aligned}
& \text { محمد عوض عبدالله" - ياسر فكرى كثك² - انعام كمال أحمد } 1 \text { - ماجدة حبيب علام2 } 2
\end{aligned}
$$

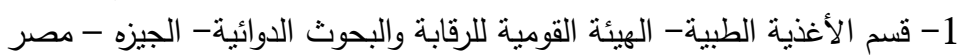

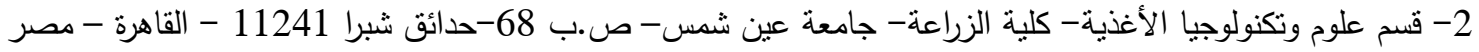

*Corresponding author: Mohamed.awad32@gmail

Received 24 March, $2019 \quad$ Accepted 14 April, 2019

الكرنب الأحمر أو خليط من البروكلى والكرنب

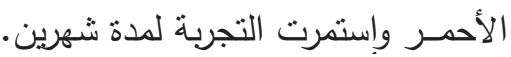

أشثارت النتائج إلى أنى عملية استئصسال المبيض

للفئران والتغذية على غذاء قياسى ناقص الكالسيوم لمدة

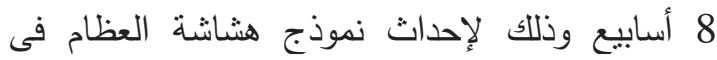

الفئران تسبب في نقصان كلا من وزن الجسم، هرمون

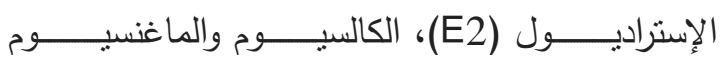

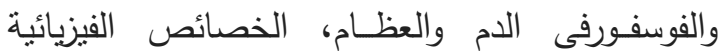
وكثافة العظام كما حدث تضخم في وزن الكبد والكلى

وزيـادة فى هرمون الغدة الدرقية (PTH) مقارنة بالجموعة الضابطة الإيجابية. وقد لوحظت أفضل

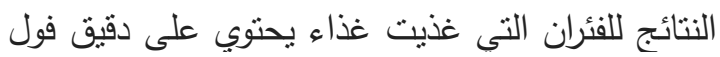

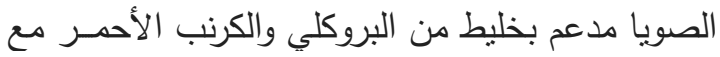

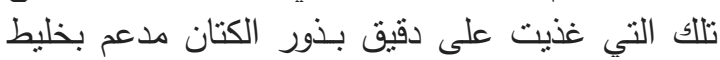

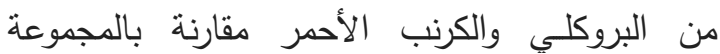

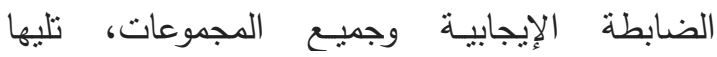
مجموعـات الفئران التي تغذت على دقئ دقيق فول الصويا

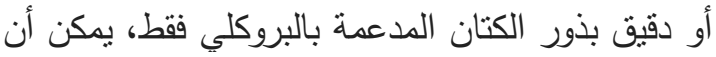

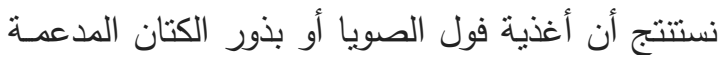

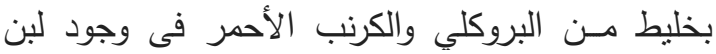

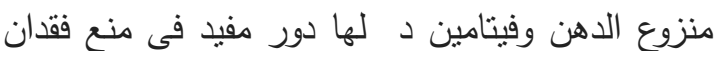
العظام والحفاظ على تكوينها وزيادة كثافتها.

الكلمات الدالة: العظام، ترقق العظام، فول الصويا، بذور الكتان، البروكلي، الكرنب الأحمر العظم
أجريت هذه الدراسة لدراسة تأثثير بعض الأغذية الصحية مثل دقيق كلا من فول الصويا وبذور

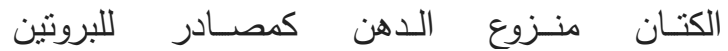
والإستروجينات النباتية وأغذية غنية بمضادات الأنية الأكسدة

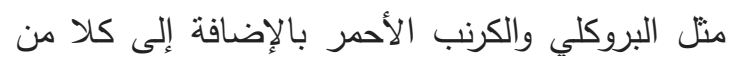
فيتامين د ولبن فرز منزوع الدسم كمصدر للكالسيوم

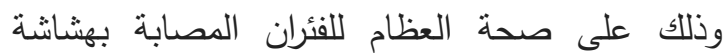
العظام. لهذا الغرض، استخدمت 96 من فئران التجارب الإناث في التجربة البيولوجية. تم أخذ مجموعة

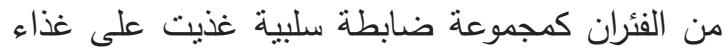
قياسى ثم إجرى عملية نزع المبايض لباقى الفئران

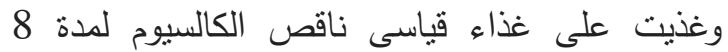
أسابيع للوصول إلى هثاشة العظام بعد ذللك نم تنسيح

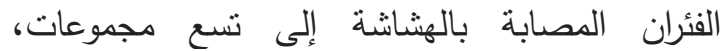
المجموعة الأولى وهى المجموعة الضابطة الايجابية

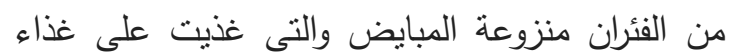

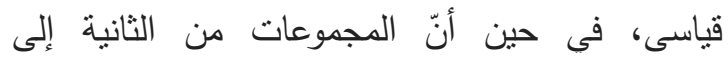
الخامسة غذّيت على دقيق فول الصويا فقط أو دقيق

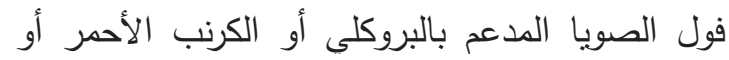

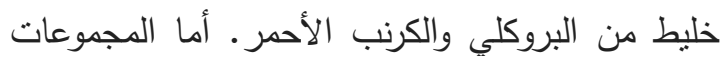

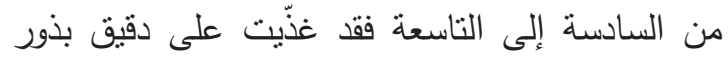
الكتان فقط أو دقيق بذور الكتان الددعم بالبروكلي أو فئ لـون 